\title{
Paideusis
}

\section{Beyond Market Theology: Reply to Barrett and Woodhouse}

\section{John McMurtry}

Volume 5, Number 2, 1992

URI: https://id.erudit.org/iderudit/1073349ar

DOI: https://doi.org/10.7202/1073349ar

See table of contents

Publisher(s)

Canadian Philosophy of Education Society

ISSN

0838-4517 (print)

1916-0348 (digital)

Explore this journal

Cite this article

McMurtry, J. (1992). Beyond Market Theology: Reply to Barrett and

Woodhouse. Paideusis, 5(2), 34-38. https://doi.org/10.7202/1073349ar

(C) John McMurtry, 1992

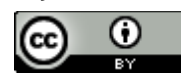

This document is protected by copyright law. Use of the services of Erudit (including reproduction) is subject to its terms and conditions, which can be viewed online.

https://apropos.erudit.org/en/users/policy-on-use/ 


\title{
Critical Responses
}

\section{Beyond Market Theology: Reply to Barrett and Woodhouse}

\author{
John McMurtry, Department of Philosophy, University of Guelph
}

I am pleased to be given the opportunity to respond to Richard Barrett's and Howard Woodhouse's stimulating replies to my article "Education and the Market Model" in the most recent issue of Paideusis 1

Because Woodhouse's paper introduces a problem which is instantiated by Barrett's reply, I will deal with it first. It consists of two main steps. First, it briefly explains the general pattern of my case, with whose argument it essentially agrees. Then it provides a revealing illustration of a main claim of my article's argument-namely, that the academic community itself has so internalized the currently dominant ideology of the "free market" that its members are sometimes unable to rationally entertain criticism of it. The case Woodhouse reports is that of two senior York University professors of philosophy, Joseph Agassi and Ian Jarvie, who replied to an earlier article of mine ${ }^{2}$ Woodhouse points out that while Agassi and Jarvie categorically deny there is any conflict whatever between market and educational goals and methods, they do not think it anywhere necessary to provide any reason or argument against the contradictions clearly identified in the article. Since the contradictions specified in the article would, Woodhouse argues, be perfectly evident to the members of a first-year philosophy class, and since, moreover, it is a normal requirement of reason to provide some justification for what you categorically deny, he concludes that Agassi and Jarvie's reply presents us with a paradigm case where "rationality has been abandoned" by unconditional adherence to market doctrine. Woodhouse suggests that in this unreasoned presupposition of a dominant form of social life we are able to see the depth of the market model's hold on the current academic mind. Are we now facing a kind of deep-structural social indoctrination where it is no longer thought conceivable to doubt the ruling ideology of the day? We might think of the problem here as akin to that of the mediaeval schoolmen in their presupposition of theological dogma. Given principles of belief are simply assumed as the ultimate ordering structure of our thoughts and our lives, even by those whose post-medieval business it is to question such conditioned certitudes.

\section{Further Evidence of the Pattern}

Barrett's reply provides us with another example of what Woodhouse calls the "abandonment of rationality." From the outset he presupposes that the market model's application to education would provide us with "increased choice among various alternatives offered independently of government." This is an apparent necessary truth for him which is nowhere diverted by my article's continuous argument against it. It is simply assumed as a given through his reply-"expanded choice," "endless possibilities of interest and challenge," "people choose where and how to study," "increase in choice," "permitting a variety," "students will actually get to make a choice," "resulting greater choice," and so on. In an otherwise desultory response of tangents and personal associations, Barrett's assumption that the market model's application to education necessarily means ever more freedom is the one unifying idea of his reply. 
As those who have read my article will know, I argue that the market model's universalization across the human condition, turning everything into an item for profitable sale from rainforests and ecosystems to students' future minds and lives, poses a problem to us because it reduces and eliminates our freedom: in proportion to the extent that nothing, including our critical thought, remains independent of its omnivorous imperative of money-making sale. Barrett has managed more or less completely to block out this argument from his mind. For him, the market is freedom, whatever evidence or reason has been produced against such an assumption. As Woodhouse has observed in the case of Professors Agassi and Jarvie, this presupposition has become so fixed as a structure of thought that no reason is any longer thought required to justify it. It has become, as it were, a secular article of faith, a self-validating absolute, to which counter-argument is ruled out $a$ priori.

In consequence of this ruling assumption, Barrett's reply, like Agassi's and Jarvie's, follows a charitable path of avoidance of counter-arguments to it. However, Barrett does raise some interesting issues to which I now reply.

\section{Elitism and Egalitarianism}

The main new issue Barrett raises has to do with the "egalitarian" versus "elitist" approach to education. I do not refer to this issue in my article, but I think it is worthwhile clarifying here that my argument has "elitist" implications in one sense, and "egalitarian" implications in another. It has elitist implications insofar as it holds throughout to the claim that an education is "earned, not bought," and that only those who are willing to eam it and to work continuously for it, are able either to achieve or to maintain it.

On the other hand, my article has "egalitarian" implications insofar as it finds the first major opposition between education and the market to be that in the market the opportunity to have a good is conferred only on those who have enough money to buy it, and only so far as its sale continuously yields money profit to its owner. Education, on the other hand, (I quote from my article), "is furthered the more it is shared," the more there is "free and open access to all of its accumulation," and the more it is achieved "independently of the moneydemand learners are able to exercise." The general implication is that the more there is public education for all, and the more access to it does not depend on private wealth, the better the educational process there will be.

This concept of education flies in the face of current fashion-for example, Allan Bloom's best-selling idea in his aptly titled The Closing of the American Mind that education should be reserved only for those "who have the money to enjoy the beautiful and the useless." 3 But it is precisely this moneydemand principle of the market which educators need to resist rather than toady to. Though Barrett indicates no such lapse of pedagogical integrity, he does altogether fail to distinguish between the commercial market and what he has confused it with, a public education "voucher system" or, in general, an educational system with more alternatives to choose from. 


\section{The Compound Fallacy of Free-Market Believers}

Barrett has committed a kind of compound fallacy now familiar in the ruling ideology of the "free market." Let M stand for the Market, and F for Freedom. The double fallacy is this: $M>F$, therefore $F>M$. The former is a fallacy because it assumes what is required to be proved, namely, that the market entails freedom. This is a begged question, and more completely so the more it fails to meet counter-arguments made explicitly against it. The second argument is also a primary fallacy, known by logicians as the fallacy of affirming the consequent. That is, it does not follow from $M>F$, even if it is true, that $\mathrm{F}$, any more than it follows from "Birds have two legs" that, "All two-legged beings are birds."

Barrett's entire reply reposes on this double fallacy. I have dealt with the first one. The second occurs every time he assumes that a choice-making alternative in education (e.g., the voucher system) is, therefore, a market alternative (i.e., competing providers selling goods for whatever price they can get to whomever has the money to purchase them). Insofar as the voucher system is a public system providing free and equal effective demand to its learners to choose among educational alternatives, it is opposite to the market both in the free and in the equal nature of the effective demand its users are afforded. No one has any more vouchers than anyone else, and all have enough to select an educational opportunity from those available. Moreover, the operation is not for the money profits of the provider, and its end goods can never be bought. Finally, the school's voucher, unlike the market's money, is unexchangeable for and uninvestable in any other good but education. Barrett has equated what is systematically opposed, again revealing to us the confusion to which the dominant market ideology can lead its believers.

The Market, the Voucher System and Competing Alternatives in Education

I agree with Barrett that the voucher system does provide educational alternatives our present primary and secondary public school systems do not. Moreover, to be fair, one might argue as well that there is an important principle in common between the market model and a voucher system and that is that each provides alternatives one can choose among, given that one has the means to make the choice. We might for this reason support the general principle of competing alternatives in education. However, we must remain very careful here to avoid confusing opposite ways of constituting competing alternatives. It might well be a good idea for the public school system to introduce a system of choosable and competing alternatives as the universities do with the same requirement of peer-review standards of academic excellence to gain and maintain an appropriate educational charter. But this is an altogether different issue from applying the market model to schools. As we have seen, principles of education and the market are opposed in purpose, method, and standard of freedom.

One need not deny that the market model has been of great historical importance in assuring the development of competing alternatives, just as the academy's method of debate, critical opposition, and contesting theories has been. There is a general linkage here on the most general level which is worthwhile recognizing. But it would be disastrous as well as absurd to infer from this that contradictory structures of competing alternatives should, therefore, be made the same. 


\section{Can there be a deeper synthesis?}

At this point, we might recall what both Woodhouse and Barrett say on the market opposition between the model and education. Woodhouse says that they are "incompatible" and "totally opposed," yet holds out hope that a "deeper synthesis" may be achieved. Barrett, too, calls for some "possible reconciling," and he raises such alternatives as the voucher system to find a way. We all agree on this point.

I think the "reconciling" or the "synthesis" is to be found in the general linkage principle defined above-the principle of competing alternatives. But this "reconciling" in no way reduces the importance of our understanding that education and the market go about realizing this principle of competing alternatives in contrary ways. In the market, one seeks more money for oneself; in education, one seeks more knowledge for all. The educational process works by the debate of ideas yielding more inclusive truth; the market process by the competition of product lines for profitable sale. And so on. Each process has its place in our world, and each can assist the other while retaining independence of function. But it will be destructive of our world, and education, if the market system of competing alternatives is imposed upon the educational system because their logics of competing alternatives are opposed, as my article has already argued at some length. Unfortunately, it is just such a process of market totalization which is now under way, by attrition and appropriation, and the academy and its professors have increasingly made its program their own. More ominously, they have aggressively promoted it in disregard of the principles of reason itself. Barrett, for example, has no difficulty in asserting that dependence on corporate financing poses no problem whatever to the academic standards or freedom of a graduate department, even though he elsewhere asserts that corporations have every right to exclude all kinds of critics from their employment. As Thoreau has said, the marketplace is "a site of humiliation." We have also observed that pro-market educators have an anti-rational strategy for answering reasons or arguments against the market model's application to education, and that is simply not to answer these objections, but rather to talk about other issues while assuming throughout the truth of the very position that is being challenged.

These are clear warning signals of reason's and public education's endangerment by a new kind of barbarism, the barbarism of a now dominant global ideology, which hymns the glories of competitive alternatives while at the same time subordinating independent spheres of life ever more compulsively and irrationally to itself. Philosophers of education, in particular, need to be aware of this pattern. So far, our membership has all too generally ignored it, or indeed, joined it. Neither education nor philosophy can be served by such conditioned submergence in an external program of private self-seeking and commercial purpose. 


\section{Notes}

${ }^{1}$ Richard Barrett, "Comments on 'Education and the Market Model"," Paideusis, 5(1), 1991, 45-49, and Howard Woodhouse, ibid., 50-52.

2John McMurtry, "Education for Sale," CAUT Bulletin, 37(7), 1990, 9-11. Joseph Agassi and I.C. Jarvie, "Education: Economic Enterprise or Intellectual Challenge?" ibid., 37(10), 1990, 28. For replies, see John McMurtry, "Reply to Agassi and Jarvie," CAUT Bulletin, 38(2), 1991, 26 and Robin Matthews, "Education for Sale, A Final Word," ibid., 26.

${ }^{3}$ Allan Bloom, The Closing of the American Mind (New York: Simon and Schuster, 1987), 279. 